\title{
KETAHANAN PANGAN BERKELANJUTAN DI KABUPATEN SUKOHARJO
}

\author{
Mohammad Isnaini Sadali \\ Departemen Geografi Pembangunan, Fakultas Geografi, Universitas Gadjah Mada \\ Bulaksumur, Depok, Sleman, D.I. Yogyakarta 55821 \\ Email: mohammad.isnaini.s@geo.ugm.ac.id
}

\begin{abstract}
Abstrak
Kabupaten Sukoharjo merupakan kota satelit yang memberi daya dukung bagi kota utamanya (Kota Solo). Pembangunan Kawasan Solo Baru dan Kartasuro sebagai kota satelit mandiri dengan konsep permukiman yang didukung oleh ketersediaan fasilitas penunjang akan berimbas pada perubahan pemanfaatan lahan. Kabupaten Sukoharjo sebagai salah satu lumbung beras nasional justru perlu diperhatikan dan dijaga. Keberadaan lahan pertanian (pangan) di Kabupaten Sukoharjo menjadi terancam oleh intensitas pembangunan kota yang mengarah pada alih fungsi lahan non terbangun (lahan pertanian) menjadi terbangun. Penelitian ini bertujuan: (1) menganalisis kebutuhan dan ketersediaan pangan, (2) menganalisis daya dukung (Carrying Capacity) lahan pertanian dalam mendukung ketahanan pangan, dan (3) melakukan estimasi kebutuhan lahan pertanian pangan di Kabupaten Sukoharjo. Sebesar 44,16\% (20.617 ha) lahan di Sukoharjo diperuntukkan untuk sawah. Daya dukung pangan secara keseluruhan di Kabupaten Sukoharjo mampu tercukupi ditunjukkan dengan nilai 1,62 yang berarti bahwa kebutuhan pangan mampu dicukupi dengan luas lahan pertanian dan produksi padi yang dihasilkan saat ini. Kebutuhan lahan pertanian pangan berkelanjutan (KLP2B) menurut kecamatan di Kabupaten Sukoharjo yang masih belum dapat dipenuhi kebutuhan pangan di wilayahnya adalah Kecamatan Kartasura. Hingga 20 tahun ke depan (2031), KLP2B yang tinggi di Kabupaten Sukoharjo masih berada di Kecamatan Grogol, Kecamatan Kartosuro, Kecamatan Mojolaban dan Kecamatan Sukoharjo.
\end{abstract}

Kata kunci: ketahanan pangan, daya dukung, pembangunan wilayah

\begin{abstract}
Sukoharjo Regency is a satellite city that provides support for its main city (Solo City). The development of Solo Baru and Kartasuro areas as self-contained satellite cities with the concept of settlements supported by the availability of supporting facilities will impact on land use change. Sukoharjo Regency as one of the national rice granary precisely needs to be considered and maintained. The existence of agricultural land (food) in Sukoharjo Regency becomes threatened by the intensity of urban development that leads to the conversion of non-built land (agricultural land) to be built. This study aims to: (1) analyze the need and availability of food, (2) analyze the carrying capacity of agricultural land in supporting food security, and (3) estimate the needs of food agriculture land in Sukoharjo Regency. A total of 44.16\% (20,617 ha) of land in Sukoharjo is reserved for rice fields. The food carrying capacity in Sukoharjo Regency as a whole is sufficiently indicated by a value of 1.62 which means that food needs can be satisfied with the existing area of agricultural land and rice production. The need for sustainable agricultural land (KLP2B) in Sukoharjo Regency that has not been fulfilled by the needs of food in its area is Kartasura District. Until the next 20 years (2031), high KLP2B in Sukoharjo Regency is still in Grogol District, Kartosuro District, Mojolaban District and Sukoharjo District.
\end{abstract}

Keywords: food security, carrying capacity, regional development 


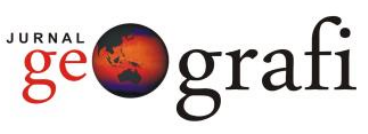

\section{PENDAHULUAN}

Kabupaten Sukoharjo merupakan kota satelit yang memberi daya dukung bagi kota utamanya (Kota Solo). Menurut McGee (1991), kota satelit biasanya dihuni oleh komuter yang berasal dari kota besar di sekitar atau kota utamanya. Kota Solo memiliki 3 (tiga) kota satelit yang terdiri dari Solo Baru, Kartasuro, dan Palur. Kota Satelit Solo Baru dan Kartasuro berada di Kabupaten Sukoharjo, sedangkan Palur berada di Kabupaten Karanganyar. Pembangunan Kawasan Solo Baru dan Kartasuro sebagai kota satelit mandiri memiliki konsep permukiman yang didukung oleh ketersediaan fasilitas penunjang seperti sarana prasarana pendidikan, kesehatan, ekonomi, hiburan/rekreasi dan fasilitas penunjang lainnya. Pusat kegiatan pada suatu wilayah mampu memberikan daya tarik bagi beberapa penduduk yang memang memiliki kepentingan dan motif tertentu dengan harapan dapat diwujudkan pada daerah tujuan (Sadali, 2014). Seiring dengan semakin bertambahnya jumlah penduduk maka pemanfaatan sumberdaya alam baik air maupun lahan terus mengalami peningkatan. Hal ini disebabkan oleh semakin meningkatnya kebutuhan pangan dan sarana penunjang baik perumahan, penyediaan air, jasa, dan pelayanan umum lainnya (Berutu, 2015).

Kabupaten Sukoharjo memiliki karakteristik wilayah yang beragam dan relevan dengan isu nasional saat ini. Keragaman dari sisi kawasan perdesaan, kawasan transisi (sub urban) dan kawasan perkotaan (urban). Kondisi inilah yang membuat penggunaan lahan di Kabupaten Sukoharjo juga beragam menjadikan penelitian ini lengkap dalam jenis lokasi kajian. Kabupaten Sukoharjo sedang melaksanakan pembangunan yang intensif di kawasan perkotaan, disisi lain Kabupaten Sukoharjo juga menjadi lumbung padi nasional. Hal ini tentunya berhubungan dengan upaya menciptakan keterkaitan (linkage) antara daerah kota dengan pinggiran kota yang seimbang dan saling menguntungkan bagi masyarakat dan perkembangan wilayah (Sadali, 2016).

Intensitas pembangunan di kota satelit ini tentu akan berdampak pada alih fungsi lahan terutama dari lahan non terbangun menjadi lahan terbangun. Seiring dengan berkembangnya kota satelit di wilayah Kabupaten Sukoharjo akan berimbas pada perubahan lanskap dengan bergesernya pemanfaatan ruang di dalamnya. Kecenderungan mobilitas penduduk yang terjadi saat ini juga lebih banyak menuju perkotaan sebagai pusat pertumbuhan wilayah dan ke arah pinggiran kota atau pusat pertumbuhan baru (Sadali, 2016). Hal yang perlu diantisipasi adalah kecenderungan alih fungsi lahan yang kurang mempertimbangkan lahan produksi untuk pertanian (pangan) karena akan mengganggu keseimbangan wilayah dalam mememenuhi kebutuhan pangan (swasembada pangan). Berkurangnya lahan produksi pertanian atau pangan di Kabupaten Sukoharjo dapat mempengaruhi keberlanjutan pemenuhan kebutuhan pangan penduduk. Dengan kata lain ketahanan pangan di Kabupaten Sukoharjo akan terganggu jika alih fungsi lahan pertanian (pangan) tidak dipertimbangkan.

Berbagai penelitian telah menunjukkan bahwa ketersediaan pangan secara global telah memasuki masa kritis. Ketersediaan pangan di banyak negara sudah tidak mampu lagi memenuhi kebutuhan pangan bagi penduduknya (Kurniawan dan Sadali, 2015). Menurut Tambunan (dalam Handani et al., 2017) kemampuan Indonesia meningkatkan produksi pertanian dalam berswasembada pangan sangat ditentukan oleh banyak faktor, baik faktor eksternal maupun internal. Salah satu faktor eksternal yang tidak bisa dipengaruhi oleh manusia adalah iklim; walaupun dengan kemajuan teknologi saat ini pengaruh negatif dari cuaca buruk terhadap produksi pertanian bisa diminimalisir. Sedangkan faktor-faktor internal (dalam arti bisa dipengaruhi oleh 
manusia), diantaranya adalah luas tanah, bibit, berbagai macam pupuk (seperti urea, TSP, dan KCL), pestisida, ketersediaan dan kualitas infrastuktur termasuk irigasi, jumlah dan kualitas SDM. Hasil penelitian Mulyani, et al. (2017) menunjukkan bahwa laju konversi lahan sawah ke non pertanian sekitar 96.500 ha per tahun, sementara laju perluasan lahan sawah hanya sekitar 20.000-30.000 ha per tahun. Lebih jauh lagi diungkap bahwa intensifikasi lahan pertanian pangan dengan inovasi teknologi pada lahan sawah irigasi maupun lahan sawah sub-optimal seperti sawah tadah hujan, irigasi sederhana, sawah rawa, dan lain-lain diperlukan untuk sebagai salah satu upaya pemenuhan swasembada pangan berkelanjutan.

Ketahanan pangan menjadi perhatian Pemerintah Kabupaten Sukoharjo, karena terkait dengan Kabupaten Sukoharjo yang merupakan salah satu lumbung beras nasional atau menjadi daerah yang mampu berswasembada beras. Hal ini juga sesuai dengan visi misi Kementerian Pertanian 2015-2019 yaitu mewujudkan kedaulatan pangan dan kesejahteraan petani. Menurut Undang-Undang Nomor 41 tahun 2009, Lahan Pertanian Pangan Berkelanjutan adalah bidang lahan pertanian yang ditetapkan untuk dilindungi dan dikembangkan secara konsisten guna menghasilkan pangan pokok bagi kemandirian, ketahanan, dan kedaulatan pangan nasional. Dengan adanya kebijakan ini sebenarnya diharapkan setiap daerah mampu memenuhi kebutuhan pangan melalui lahan pertanian yang dimiliki daerah tersebut. Dengan demikian, lahan sebagai sumberdaya alam dalam pembangunan perlu dijaga terutama lahan pertanian. Di Kabupaten Sukoharjo, salah satu lahan pertanian yang menjadi penyokong kebutuhan pangan adalah padi.

Penelitian ini dilaksanakan untuk mengetahui kebutuhan dan ketersediaan pangan dengan menekankan pada kemampuan daya dukung (Carrying Capacity) lahan pertanian (pangan) dalam mendukung ketahanan pangan di Kabupaten Sukoharjo. Agar ketahanan pangan di Kabupaten Sukoharjo dapat terjamin keberlanjutannya, maka dilakukan perhitungan estimasi kebutuhan pangan dan ketersediaan lahan pertanian (pangan) dalam beberapa tahun ke depan. Penelitian ini juga mendukung kebijakan pemerintah pusat maupun daerah dalam mewujudkan ketahanan pangan dan menjaga lahan pertanian pangan berkelanjutan (LP2B).

\section{METODE PENELITIAN}

Penelitian ini menggunakan metode penelitian kuantitatif, dengan data sekunder sebagai data utama dan dilakukan analisis secara deskriptif. Cakupan wilayah dalam penelitian ini dilakukan di seluruh Kabupaten Sukoharjo yang terdiri dari 12 kecamatan, yaitu Weru, Bulu, Tawangsari, Sukoharjo, Nguter, Bendosari, Polokarto, Mojolaban, Grogol, Baki, Gatak, dan Kartasura. Berdasarkan data Kabupaten Sukoharjo dalam Angka Tahun 2016, sebagian besar status daerah di sana masih desa.

Lokasi penelitian ini dipilih dengan didasari oleh beberapa pertimbangan: (1) Kabupaten Sukoharjo memiliki karakteristik wilayah yang beragam dan relevan. Keragaman dari sisi kawasan perdesaan, kawasan transisi (sub urban) dan kawasan perkotaan (urban). Kondisi inilah yang membuat penggunaan lahan di Kabupaten Sukoharjo juga beragam menjadikan penelitian ini lengkap dalam jenis lokasi kajian, (2) Isu ketahanan pangan di Kabupaten Sukoharjo sudah menjadi perhatian para pemangku kebijakan (pemerintah), hal ini tercermin dengan upaya pemerintah untuk mewujudkan LP2B di Kabupaten Sukoharjo, dan (3) Kabupaten Sukoharjo sedang melaksanakan pembangunan yang intensif di kawasan perkotaan, disisi lain Kabupaten Sukoharjo juga menjadi lumbung padi nasional. 
Indikator yang digunakan dalam penelitian ini mengadopsi salah satu indikator peta kerentanan dan ketahanan pangan yang digunakan Word Food Programme dari PBB dan Undang-undang
No. 7 tahun 1996 tentang Pangan. Indikator utama yang digunakan adalah ketersediaan pangan dan kebutuhan pangan, seperti yang ditunjukkan pada Tabel 1 berikut ini.

Tabel 1. Indikator Ketahanan Pangan

\begin{tabular}{|c|l|}
\hline Indikator & \multicolumn{1}{c|}{ Cara Pengukuran } \\
\hline $\begin{array}{c}\text { Ketersediaan } \\
\text { Pangan }\end{array}$ & $\begin{array}{l}\text { - Luas lahan pertanian } \\
\text { - Produktivitas lahan pertanian }\end{array}$ \\
\hline $\begin{array}{c}\text { Kebutuhan } \\
\text { Pangan }\end{array}$ & $\begin{array}{l}\text { - Jumlah penduduk; } \\
\text { - Rasio konsumsi normatif per } \\
\text { kapita terhadap ketersediaan } \\
\text { bahan pangan. }\end{array}$ \\
\hline
\end{tabular}

Sumber: Hasil penyesuaian WFP, 2015

Formulasi yang digunakan dalam menghitung ketersediaan dan kebutuhan pangan di Kabupaten Sukoharjo dilakukan melalui pendekatan daya dukung pangan pada suatu wilayah yang merupakan hasil kolaborasi dan modifikasi rumus yang bersumber dari Odum, Christeiler, Ebenezer Howard dan Issard di dalam buku Soehardjo dan Tukiran tahun 1990. Rumus yang digunakan adalah:

$$
\tau=\frac{\operatorname{Lp} / P d}{\mathrm{KPB} /(\operatorname{Pr} \times 0,632)}
$$

Keterangan:

$\tau$ : Daya dukung wilayah pertanian (DDW)

Lp : Luas panen (ha)

Pd : Jumlah penduduk (jiwa)

KPB : Kebutuhan pangan beras perkapita, yaitu sebesar 154,1

$\mathrm{kg} /$ kapita/tahun (Badan Ketahanan Nasional)

Pr : Produksi lahan rata-rata per hektar (kg/ha)

0,632: Konstanta ubah dari padi ke beras

Prinsip dari perhitungan di atas mengasumsikan bahwa suatu daerah mampu memenuhi kebutuhan pangannya jika nilai yang dihasilkan dari perhitungan daya dukung pangannya 1 (satu) atau lebih. Sehingga rumus yang digunakan dalam menghitung kebutuhan lahan pertanian (melalui pendekatan luas panen) adalah:

$$
\mathrm{Lp}=\mathrm{KPB} /(\operatorname{Pr} \times 0,632) \times \mathrm{Pd}
$$

Keterangan

LP : Luas panen

KPB : Kebutuhan Pangan Beras perkapita, yaitu sebesar 154,1

$\mathrm{kg} / \mathrm{kapita} /$ tahun (Badan

Ketahanan Nasional)

$\operatorname{Pr} \quad$ : Frekuensi panen $(2 x /$ tahun $)$

0,632 : Konstanta ubah dari padi ke beras

Maka rumus yang dapat digunakan untuk menghitung Kebutuhan Lahan Pertanian Pangan Berkelanjutan adalah:

$$
\mathrm{KLP} 2 \mathrm{~B}=\mathrm{Lp} / \mathrm{Fr}
$$

Keterangan

KLP2B : Kebutuhan lahan pertanian pangan berkelajutan

Fr $\quad$ : Frekuensi panen $(2 \mathrm{x} /$ tahun $)$

\section{HASIL DAN PEMBAHASAN \\ Ketersediaan Pangan}

Kabupaten Sukoharjo secara administratif terbagi menjadi 12 kecamatan dengan total luas wilayah sebesar 46.666 ha (lihat Tabel 2). Masingmasing kecamatan di wilayah tersebut memiliki variasi luas yang beragam. Kecamatan terluas adalah Polokarto yang mencapai $13,3 \%$ dari luas total. Kecamatan Polokarto ini berada di bagian timur laut Sukoharjo (lihat Gambar 1). 


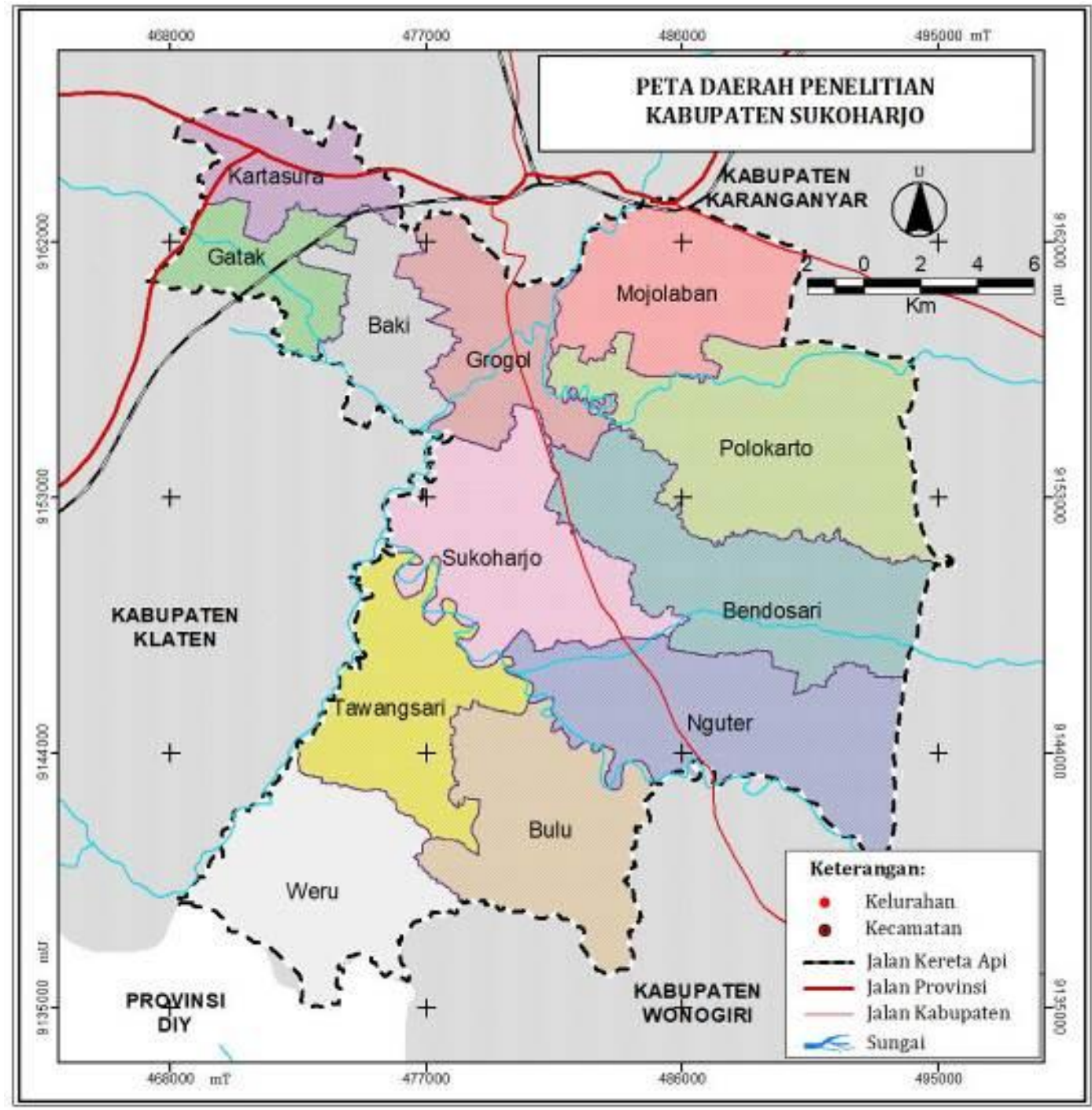

Gambar 1. Peta Daerah Penelitian

Kabupaten Sukoharjo merupakan salah satu Kabupaten di Jawa Tengah yang memiliki potensi di bidang pertanian khususnya pada lahan pangan. Hal tersebut dibuktikan dengan masih cukup luasnya lahan yang diperuntukkan untuk sawah maupun lahan pertanian pangan yang lain. Berdasarkan data statistik dari BPS yang ditunjukkan pada Tabel 2, bahwa 44,16\% (20.617 ha) lahan di Sukoharjo diperuntukkan untuk sawah. Sisanya (55,84\%) lahan atau seluas 26.049 ha merupakan lahan bukan sawah.

Kecamatan yang memiliki luas lahan sawah terluas adalah Kecamatan Bendosari dengan luas lahan $2.528 \mathrm{Ha}$, sedangkan untuk kecamatan yang memiliki luas penggunaan lahan sawah paling kecil yaitu Kecamatan Kartasura.
Kecamatan Kartasura didominasi oleh lahan bukan sawah dikarenakan wilayah tersebut merupakan pusat perkembangan di Kabupaten Sukoharjo sekaligus sering disebut sebagai kota satelit bagi Kota Solo. Oleh karena itu, sektor non pertanian lebih berkembang di wilayah ini.

Jenis komoditas tanaman pangan yang diproduksi di Kabupaten Sukoharjo bervariasi. Terdapat 7 (tujuh) komoditas tanaman pangan, yaitu Padi Sawah dan Gogo, Jagung, Ubi Kayu, Ubi Jalar, Kacang Tanah, Kedelai, serta Kacang Hijau. Produksi tanaman bahan makanan di Kabupaten Sukoharjo selama 3 (tiga) tahun ini dari tahun 2012 hingga tahun 2014 mengalami fluktuasi. Produksi tanaman pangan di Kabupaten Sukoharjo pada tahun 2012 sebesar 278.119 ton. Pada 
tahun 2013 produksi tanaman pangan mengalami peningkatan hingga mencapai 423.289 ton kemudian mengalami penurunan lagi pada tahun 2014 dengan produksi sebesar 390.937 ton.

Tabel 2. Luas Wilayah, Luas Wilayah Lahan Sawah dan Bukan Lahan Sawah Menurut

Kecamatan di Kabupaten Sukoharjo Tahun 2016

\begin{tabular}{|c|c|c|c|c|c|}
\hline \multirow{2}{*}{ No } & \multirow{2}{*}{ Kecamatan } & \multicolumn{2}{|c|}{ Luas Wilayah } & \multicolumn{2}{|c|}{$\begin{array}{c}\text { Luas Lahan Sawah dan Bukan } \\
\text { Sawah }\end{array}$} \\
\hline & & $\begin{array}{l}\text { Luas } \\
\text { (ha) }\end{array}$ & $\begin{array}{l}\text { Persentase } \\
\quad(\%)\end{array}$ & $\begin{array}{l}\text { Lahan Sawah } \\
\text { (ha) }\end{array}$ & $\begin{array}{c}\text { Bukan Lahan } \\
\text { Sawah (ha) }\end{array}$ \\
\hline 1 & Weru & 4.198 & 9,00 & 2.031 & 2.167 \\
\hline 2 & Bulu & 4.386 & 9,40 & 1.131 & 3.255 \\
\hline 3 & Tawangsari & 3.998 & 8,57 & 1.677 & 2.321 \\
\hline 4 & Sukoharjo & 4.458 & 9,55 & 2.363 & 2.095 \\
\hline 5 & Nguter & 5.488 & 11,76 & 2.418 & 3.070 \\
\hline 6 & Bendosari & 5.299 & 11,36 & 2.528 & 2.771 \\
\hline 7 & Polokarto & 6.218 & 13,32 & 2.453 & 3.765 \\
\hline 8 & Mojolaban & 3.554 & 7,62 & 2.161 & 1.393 \\
\hline 9 & Grogol & 3.000 & 6,43 & 934 & 2.066 \\
\hline 10 & Baki & 2.197 & 4,71 & 1.241 & 956 \\
\hline 11 & Gatak & 1.947 & 4,17 & 1.209 & 738 \\
\hline 12 & Kartasura & 1.923 & 4,12 & 471 & 1.452 \\
\hline & Total & 46.666 & 100,00 & 20.617 & 26.049 \\
\hline
\end{tabular}

Sumber: Kabupaten Sukoharjo Dalam Angka, 2016

Fluktuasi hasil produksi tanaman pangan ini disebabkan oleh faktor produktivitas lahan yang tidak menentu serta ketersediaan lahan untuk tanaman pangan. Semakin luas lahan panen serta produktivitas lahan, maka produksinya juga akan meningkat. Jika dilihat dari produktivitasnya, tidak semua lahan pertanian mempunyai produktivitas yang tinggi, sebagian lahan pertanian mempunyai produktivitas yang rendah terutama pada lahan pertanian yang merupakan lahan pertanian kering atau lahan pertanian tadah hujan (Kurniawan dan Sadali, 2015).

Berdasarkan data komoditas tanaman pangan di Sukoharjo pada Tabel 3, Komoditas tanaman pangan di Kabupaten Sukoharjo yang memiliki produksi cukup tinggi selanjutnya adalah ubi kayu. Meskipun demikian, kecenderungan produksi ubi kayu di Kabupaten Sukoharjo dari tahun 20122014 terus menurun, mulai dari 45.339 ton pada tahun 2012 menjadi 25.743 ton pada tahun 2014. Komoditas tanaman pangan selain padi sawah dan gogo, semuanya mengalami penurunan dari tahun ke tahun, dengan demikian dapat disimpulkan bahwa potensi padi sawah dan gogo di Kabupaten Sukoharjo sangat besar.

Ubi Jalar merupakan komoditas yang paling sedikit diproduksi. Bahkan pada tahun 2012 produksi dari komoditas Ubi Jalar tidak ada atau 0 (nol). Hal tersebut dikarenakan lahan tanam yang digunakan juga minim dibandingkan untuk komoditas lain. Produksi komoditas padi sawah dan gogo di Kabupaten Sukoharjo dari tahun ke tahun selalu mengalami peningkatan dan mendominasi produksi tanaman pangan. Hal ini menunjukkan bahwa luas lahan dan hasil panen komoditas padi sawah dan gogo di Kabupaten Sukoharjo sangat tinggi dan masih banyak diusahakan oleh masyarakat maupun kelompok (non perorangan). 
Komoditas tanaman pangan di Kabupaten Sukoharjo yang memiliki produksi cukup tinggi selanjutnya adalah ubi kayu. Meskipun demikian, kecenderungan produksi ubi kayu di Kabupaten Sukoharjo dari tahun 20122014 terus menurun, mulai dari 45.339 ton pada tahun 2012 menjadi 25.743 ton pada

Tabel 3. Produksi Tanaman Bahan Makanan menurut Komoditas di Kab. Sukoharjo Tahun 2012-2014 (Ton)

\begin{tabular}{|l|c|c|c|}
\hline \multirow{2}{*}{ Komoditas } & \multicolumn{3}{|c|}{ Tahun } \\
\cline { 2 - 4 } & $\mathbf{2 0 1 2}$ & $\mathbf{2 0 1 3}$ & $\mathbf{2 0 1 4}$ \\
\hline $\begin{array}{l}\text { Padi Sawah dan } \\
\text { Gogo }\end{array}$ & 185.653 & 346.039 & 327.182 \\
\hline Jagung & 28.717 & 23.939 & 21.424 \\
\hline Ubi Kayu & 45.339 & 35.155 & 25.743 \\
\hline Ubi Jalar & 0 & 19 & 12 \\
\hline Kacang Tanah & 13.179 & 12.990 & 12.989 \\
\hline Kedelai & 5.054 & 5.007 & 3.523 \\
\hline Kacang Hijau & 177 & 140 & 64 \\
\hline Total & 278.119 & 423.289 & 390.937 \\
\hline
\end{tabular}

Sumber: Kabupaten Sukoharjo dalam Angka, 2016

Konsumsi pangan pokok masih bertumpu pada beras, beras merupakan pangan pokok utama masyarakat Indonesia, sehingga pemerintah selalu menempatkan beras sebagai komoditas yang selalu tersedia dan cukup (Syahril et al., 2015). Konsumsi pangan pokok di Kabupaten Sukoharjo, di daerah sekitar dan Jawa pada umumnya memang berupa beras yang dihasilkan oleh tanaman padi, sehingga relevan jika pengembangan komoditas tanaman pangan di Kabupaten Sukoharjo mengarah pada padi sawah dan gogo. Kebutuhan pangan masyarakat sebagai demand (permintaan pasar) terhadap produk komoditas padi menjadi salah satu alasan pengembangan pertanian pangan. Agar ketersediaan produk pangan dapat secara kontinu diciptakan maka diperlukan strategi pengembangan pertanian melalui pengaturan pola tanam, pemilihan komoditas, dan siklus panen (Syarief, 2017).

\section{Analisis Daya Dukung Pangan}

tahun 2014. Komoditas tanaman pangan selain padi sawah dan gogo, semuanya mengalami penurunan dari tahun ke tahun, dengan demikian dapat disimpulkan bahwa potensi padi sawah dan gogo di Kabupaten Sukoharjo sangat besar. 


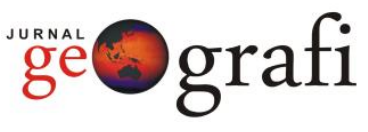

(dua) kecamatan yang memiliki nilai daya dukung pangan kurang dari 1, yaitu Kecamatan Kartasura (0,37) dan Kecamatan Grogol $(0,60)$. Hal ini juga dipengaruhi jumlah penduduk yang ada di Kecamatan Kartasura dan Kecamatan Grogol sangat tinggi dibandingkan dengan kecamatan lain, sehingga kebutuhan akan pangan juga semakin meningkat. Sesuai dengan pendapat Mantra (2007), bahwa penurunan daya dukung lahan dipengaruhi oleh jumlah penduduk yang terus meningkat, luas lahan yang semakin berkurang, persentase jumlah petani dan luas lahan yang diperlukan untuk hidup layak.

Dengan kata lain dua kecamatan tersebut (Kecamatan Kartasura dan Kecamatan Grogol) membutuhkan pasokan pangan dari daerah lain untuk memenuhi kebutuhan pangan (atau berswasembada pangan) di kecamatan masing-masing, karena lahan pertanian dan produksi pangan di dua kecamatan tersebut tidak mampu menopang kebutuhan pangannya sendiri.

Kecamatan Kartasura merupakan bagian dari Kota Solo Baru atau Kota Satelit dari Kota Solo, sehingga perkembangan penggunaan lahan dan aktivitas pembangunan yang intensif menjadi salah satu penyebab berkurangnya lahan pertanian pangan dan produktivitasnya. Sedangkan
Kecamatan Grogol memiliki letak yang strategis dalam hal kedekatannya dengan Kota Solo dan kemudahan akses ke daerah sekitarnya (Surakarta, Kartasura, Boyolali, dan Karanganyar). Karena letaknya di perbatasan dan strategis, maka Kecamatan Grogol yang dulunya merupakan daerah pertanian bergeser menjadi daerah perkembangan pendidikan, kesehatan, ekonomi dan jasa. Kecamatan Grogol memiliki fasilitas pendidikan yang lengkap, rumah sakit, pusat perbelanjaan, daerah wisata, perhotelan, dan industri.

Berdasarkan Tabel 4, kecamatan yang memiliki daya dukung pangan yang tinggi berada di Kecamatan Nguter, Kecamatan Bendosari dan Kecamatan Polokarto. Ketiga kecamatan tersebut memiliki nilai daya dukung pangan di atas 2, yang artinya lahan pertanian dan produksinya sudah mampu memenuhi kebutuhan pangan dan mampu diekspor atau menyokong kebutuhan pangan di daerah lain. Nilai daya dukung pangan pada masing-masing kecamatan adalah 2,33 untuk Kecamatan Polokarto, 2,30 untuk Kecamatan Bendosari, dan 2,26 untuk Kecamatan Nguter. Dengan demikian proporsi antara ketersediaan pangan (luas lahan dan produksi pertanian) dengan jumlah penduduk di kecamatan tersebut sudah mencukupi.

Tabel 4. Perhitungan Daya Dukung Pangan dan Kebutuhan Lahan Pertanian Pangan Berkelanjutan di Kabupaten Sukoharjo Tahun 2015

\begin{tabular}{|c|c|c|c|c|c|c|c|c|c|}
\hline No & Kecamaatan & $\begin{array}{c}\text { Penduduk } \\
2014\end{array}$ & $\begin{array}{c}\text { KPB (Kg/Kapita/ } \\
\text { Tahun) }\end{array}$ & $\begin{array}{c}\text { Hasil Padi ke } \\
\text { Beras }\end{array}$ & $\begin{array}{c}\text { Luas Panen } \\
\text { (Ha) }\end{array}$ & $\begin{array}{c}\text { Produksi } \\
\text { (Ton) }\end{array}$ & $\begin{array}{c}\text { Produksi } \\
\text { Lahan Sawah } \\
(\mathrm{Kg} / \mathrm{Ha})\end{array}$ & $\begin{array}{c}\text { Daya Dukung } \\
\text { Pangan }\end{array}$ & KLP2B \\
\hline 1 & Weru & 67.431 & 154,1 & 0,632 & 4.790 & 32.730 & 6.833 & 1,99 & 1.220 \\
\hline 2 & Bulu & 51.684 & 154,1 & 0,632 & 2.254 & 15.770 & 6.996 & 1,25 & 914 \\
\hline 3 & Tawangsari & 59.552 & 154,1 & 0,632 & 3.391 & 23.913 & 7.052 & 1,65 & 1.044 \\
\hline 4 & Sukoharjo & 86.794 & 154,1 & 0,632 & 5.332 & 37.597 & 7.051 & 1,78 & 1.522 \\
\hline 5 & Nguter & 64.970 & 154,1 & 0,632 & 5.220 & 35.741 & 6.847 & 2,26 & 1.174 \\
\hline 6 & Bendosari & 68.586 & 154,1 & 0,632 & 5.639 & 38.401 & 6.810 & 2,30 & 1.246 \\
\hline 7 & Polokarto & 75.591 & 154,1 & 0,632 & 6.028 & 42.938 & 7.123 & 2,33 & 1.312 \\
\hline 8 & Mojolaban & 81.717 & 154,1 & 0,632 & 5.642 & 36.214 & 6.419 & 1,82 & 1.575 \\
\hline 9 & Grogol & 107.555 & 154,1 & 0,632 & 2.347 & 15.773 & 6.720 & 0,60 & 1.979 \\
\hline 10 & Baki & 54.766 & 154,1 & 0,632 & 2.765 & 18.610 & 6.731 & 1,39 & 1.006 \\
\hline 11 & Gatak & 50.347 & 154,1 & 0,632 & 3.108 & 20.845 & 6.707 & 1,70 & 928 \\
\hline \multirow[t]{2}{*}{12} & Kartasura & 94.700 & 154,1 & 0,632 & 1.267 & 8.650 & 6.827 & 0,37 & 1.716 \\
\hline & Jumlah & 863.693 & & & 47.783 & 327.182 & 82.116 & 1,62 & $15.636,6$ \\
\hline
\end{tabular}

Sumber: Hasil analisis, 2017 
Ketahanan pangan di Kabupaten Sukoharjo secara menyeluruh masih dapat terpenuhi, hal ini dapat dilihat dengan kemampuan daerah dalam memenuhi daya dukung pangan. Dengan kata lain kebutuhan pangan di Kabupaten Sukoharjo sudah dapat dipenuhi dengan ketersediaan pangan, hal ini sesuai dengan Undang-undang No. 7 tahun 1996 tentang Pangan yang mengartikan bahwa Ketahanan Pangan sebagai kondisi terpenuhinya pangan bagi rumah tangga yang tercermin dari tersedianya pangan yang cukup. Menurut World Food Summit (2015), ketahanan pangan di Kabupaten Sukoharjo dalam kajian ini dapat dikategorikan dalam konsep ketahanan pangan regional.

\section{Analisis Kebutuhan Lahan Pertanian}

Analisis kebutuhan lahan pertanian pangan berkelanjutan di Kabupaten Sukoharjo dilakukan dengan membandingkan luas lahan pertanian pangan (luas panen) eksisting dengan kebutuhan lahan pertanian pangan sesuai dengan standar kebutuhan pangan perkapita. Isu mengenai kebutuhan lahan pertanian pangan menjadi perhatian Dewan Ketahanan Pangan (DKP) seiring dengan laju pertumbuhan penduduk dan percepatan konsumsi penduduk. Ketersediaan pangan di Indonesia masih mencukupi dari sisi volumenya, akan tetapi tantangan muncul dari laju pertumbuhan penduduk yang lebih cepat dibandingkan laju pertumbuhan produksi pangan di Indonesia.

Berdasarkan data BPS (2017), ratarata laju pertumbuhan penduduk dalam 5 (lima) tahun terakhir sebesar $1,34 \%$ atau sekitar 3,4 juta jiwa per tahun, sehingga pada tahun 2017 penduduk di Indonesia mencapai 258,7 juta jiwa. Implikasi laju pertumbuhan penduduk yang tinggi terhadap kebutuhan pangan adalah dorongan terhadap laju percepatan konsumsi masyarakat/penduduk. Menurut Rusdiana et al. (2017), pertumbuhan ekonomi juga dapat berpengaruh terhadap ketahanan pangan, sesuai dengan pertambahan jumlah penduduk, per kapita dan nilai ekonomi di masyarakat yang meningkat.

Penyediaan lahan pertanian pangan untuk memenuhi konsumsi masyarakat juga selalu terencana dengan alih fungsi lahan. Pemerintah melalui UndangUndang No. 41 tahun 2009 tentang lahan pertanian pangan berkelanjutan (LP2B) berupaya mengendalikan laju konversi lahan pertanian pangan. Kabupaten/Kota di Indonesia yang belum memasukkan LP2B dalam Rencana Tata Ruang Wilayah diprediksi sekitar 5 juta ha lahan sawah rawan terkonversi menjelang tahun 2030 (Direktorat Jenderal PSP, 2014). Hasil analisis kajian lahan pertanian oleh Mulyani et al. (2016) menunjukkan bahwa laju konversi lahan nasional di 9 provinsi sentra produksi padi sekitar 96.500 ha per tahun dan diprediksikan menjelang tahun 2045 lahan sawah akan hilang seluas 2,1 juta ha (tersisa 6 juta ha). Hal ini tentunya mengancam penyediaan pangan, swasembada pangan dan pangan nasional. Oleh karena itu pengawasan, pengendalian, dan regulasi yang ketat perlu diterapkan di Kabupaten Sukoharjo maupun nasional.

Sebagian besar produksi padi nasional berasal dari lahan sawah irigasi $(67,5 \%)$ dan sawah tadah hujan $(27,5 \%)$. Kedua sawah tersebut (43\%) diantaranya terdapat di Pulau Jawa (Wahyunto, 2014). Kabupaten Sukoharjo menjadi salah satu penghasil beras dengan lahan pertanian yang sebagian besar berasal dari sawah irigasi. Pembangunan pertanian memiliki dimensi luas serta melibatkan banyak aspek dan sektor pembangunan lainnya, keberhasilan pembangunan pertanian sangat ditentukan tidak hanya oleh performa sektor pertanian semata namun juga oleh sektor lainnya yang menunjang kegiatan pertanian (Arifa D., 2017).

Secara umum kebutuhan lahan pertanian pangan berkelanjutan di Kabupaten Sukoharjo pada tahun 2014 juga masih dapat terpenuhi, hal ini ditunjukkan dengan luas panen dari lahan pertanian yang surplus atau lebih besar 
(47.783 Ha) dibandingkan dengan kebutuhan lahan pertanian $(15.636,6 \mathrm{Ha})$ untuk menyuplai pangan di Kabupaten Sukoharjo (lihat Tabel 4). Dengan luas lahan panen sebesar $47.783 \mathrm{Ha}$, dapat menghasilkan produksi pertanian sebesar $82.116 \mathrm{~kg} / \mathrm{ha}$. Surplus luas lahan pertanian yang dapat mendukung kebijakan LP2B terutama untuk Kabupaten Sukoharjo sendiri masih sebesar 32.146 Ha.

Kebutuhan lahan pertanian pangan berkelanjutan menurut kecamatan di Kabupaten Sukoharjo yang masih belum dapat memenuhi kebutuhan pangan di wilayahnya adalah Kecamatan Kartasura. KLP2B (kebutuhan lahan pertanian pangan berkelanjutan) di Kecamatan Kartasura pada tahun 2014 sebesar 1.716 Ha sedangkan luas lahan pertanian eksisting yang ada sebesar 1.267 Ha. Dengan demikian luas lahan pertanian yang masih dibutuhkan untuk memenuhi LP2B di Kecamatan Kartasura sebesar 449 Ha. Perkembangan wilayah di Kecamatan Kartasura sebagai bagian dari Kota Solo Baru berdampak pada alih fungsi pemanfaatan lahan pertanian menjadi lahan non pertanian maupun terbangun. Selain itu jumlah penduduk yang besar di
Kecamatan Kartasura belum bisa tercukupi oleh luas lahan pertanian dan produksi pertanian sebagai sumber pangan di daerah ini yang relatif kecil dibandingkan dengan kecamatan lain di Kabupaten Sukoharjo.

Kecamatan yang memiliki luas lahan pertanian cukup besar untuk mendukung LP2B di Kabupaten Sukoharjo adalah Polokarto (6.028 Ha), Kecamatan Mojolaban (5.642 Ha), dan Kecamatan Bendosari (5.639 Ha). Selaras dengan luas lahan pertanian tersebut, Kecamatan Polokarto dan Kecamatan Bendosari juga memiliki daya dukung pangan yang tinggi (2,33 dan 2,30$)$ dibandingkan kecamatan lain. Berbeda halnya dengan Kecamatan Mojolaban, nilai daya dukung pangan di kecamatan ini lebih rendah, yaitu 1,82. Perbedaan nilai daya dukung ini salah satunya disebabkan oleh perbedaan jumlah penduduk pada masing-masing kecamatan yang merupakan representasi dari kebutuhan pangan di suatu wilayah. Jumlah penduduk di Kecamatan Mojolaban sebesar 81.717 jiwa, lebih besar dari Kecamatan Polokarto (75.591 jiwa) dan Kecamatan Bendosari (68.586 jiwa).

Tabel 5. Estimasi Kebutuhan Lahan Pertanian Pangan Berkelanjutan di Kabupaten

Sukoharjo Pada Tahun 2015-2031

\begin{tabular}{|c|c|c|c|c|c|c|}
\hline \multirow{2}{*}{ No } & \multirow{2}{*}{ Kecamaatan } & \multicolumn{5}{|c|}{ Kebutuhan LP2B } \\
\hline & & 2015 & 2016 & 2021 & 2026 & 2031 \\
\hline 1 & Weru & $1.222,3$ & $1.224,8$ & $1.237,5$ & $1.250,1$ & 1. 262,8 \\
\hline 2 & Bulu & 911,4 & 911,4 & 911,5 & 911,6 & 911,7 \\
\hline 3 & Tawangsari & $1.046,8$ & $1.050,3$ & $1.067,9$ & $1.085,5$ & $1.103,0$ \\
\hline 4 & Sukoharjo & $1.531,2$ & $1.540,7$ & $1.588,1$ & $1.635,6$ & $1.683,0$ \\
\hline 5 & Nguter & $1.172,9$ & $1.174,8$ & 1. 184,3 & $1.193,8$ & $1.203,3$ \\
\hline 6 & Bendosari & $1.251,6$ & $1.257,5$ & $1.287,0$ & $1.316,5$ & $1.346,0$ \\
\hline 7 & Polokarto & $1.317,0$ & $1.321,7$ & $1.345,4$ & $1.369,1$ & $1.392,8$ \\
\hline 8 & Mojolaban & $1.583,6$ & $1.596,0$ & $1.658,0$ & $1.720,0$ & $1.781,9$ \\
\hline 9 & Grogol & $1.994,4$ & $2.013,5$ & $2.109,0$ & $2.204,5$ & $2.300,0$ \\
\hline 10 & Baki & $1.013,0$ & $1.021,7$ & $1.065,2$ & $1.108,7$ & $1.152,2$ \\
\hline 11 & Gatak & 933,9 & 942,1 & 982,7 & $1.023,3$ & $1.063,9$ \\
\hline 12 & Kartasura & $1.734,4$ & $1.751,4$ & $1.836,3$ & $1.921,2$ & $2.006,1$ \\
\hline & Jumlah & $15.712,5$ & $15.805,8$ & $16.272,9$ & $16.739,9$ & $17.206,9$ \\
\hline
\end{tabular}

Sumber: Hasil analisis, 2017 
Perhitungan yang dilakukan untuk menghitung estimasi KLP2B di Kabupaten Sukoharjo menggunakan asumsi bahwa luas panen dan produksi lahan rata-rata per hektar adalah sama dengan tahun awal perhitungan (2014). KLP2B dihitung dengan mempertimbangkan tren perkembangan penduduk yang mempengaruhi kebutuhan pangan perkapita, sehingga dapat diketahui KLP2B berdasarkan produktivitas lahan. Luas lahan pertanian dan produktivitas lahan pertanian sebagai supply (penyedia/ketersediaan pangan), sedangkan perkembangan penduduk sebagai demmand (kebutuhan pangan).

Hasil pengolahan data estimasi kebutuhan lahan pertanian pangan berkelanjutan (lihat Tabel 5) menunjukkan bahwa tren KLP2B di Kabupaten Sukoharjo masih cenderung sama dengan tahun awal (2014). Kecamatan yang sedikit membutuhkan LP2B paling kecil berada di Kecamatan Bulu dengan luas lahan yang dibutuhkan hingga tahun 2031 masih di bawah 1.000 Ha. Hingga 20 tahun ke depan (2031), KLP2B yang tinggi di Kabupaten Sukoharjo masih berada di Kecamatan Grogol, Kecamatan Kartosuro, Kecamatan Mojolaban dan Kecamatan Sukoharjo. Kebutuhan KLP2B tertinggi hingga tahun 2031 berada di Kecamatan Grogol dengan luas lahan $2.300 \mathrm{Ha}$, disusul Kecamatan Kartasura dengan luas KLP2B sebesar 2.006,1 Ha dan Kecamatan Sukoharjo dengan luas KLP2B sebesar $1.683 \mathrm{Ha}$.

\section{KESIMPULAN}

Terdapat beberapa faktor yang menentukan daya dukung pangan: 1) luas lahan pertanian pangan, 2) frekuensi panen, 3) produktivitas lahan pertanian, dan 4) jumlah penduduk. Ketahanan pangan di Kabupaten Sukoharjo dianalisis dengan menggunakan pendekatan ketersediaan pangan dan kebutuhan pangan. Ketahanan pangan akan terpenuhi atau tercukupi apabila ketersediaan pangan (produksi pangan) dapat memenuhi kebutuhan pangan penduduk pada satu daerah.

Ketahanan pangan di Kabupaten Sukoharjo masih dapat dipenuhi yang ditunjukkan dengan nilai daya dukung pangan Kabupaten Sukoharjo sebesar 1,62 (mampu berswasembada pangan). Terdapat 2 (dua) kecamatan yang memiliki ketahanan pangan cukup rentan karena kebutuhan pangan tidak bisa dicukupi oleh ketersediaan pangan di daerah tersebut, yaitu Kecamatan Kartasuro dan Kecamatan Grogol dengan ditunjukkan nilai daya dukung masingmasing sebesar 0,37 dan 0,60. Kebutuhan lahan pertanian pangan berkelanjutan (KLP2B) tertinggi dari tahun 2015 hingga 2031 di Kabupaten Sukoharjo juga berada di Kecamatan Kartasuro dan Kecamatan Grogol.

\section{UCAPAN TERIMAKASIH}

Penulis menyampaikan terima kasih kepada Heni Ermawati dan Tika Nurwidiani yang telah membantu mencari data dalam penelitian ini. Terima kasih juga disampaikan kepada Dr. Andri Kurniawan, M.Si. dan Tim Evaluator Tata Ruang Wilayah Fakultas Geografi UGM yang banyak berbagi konsep maupun data.

\section{DAFTAR PUSTAKA}

Arifa, N.S.A. (2017). Harmonisasi Kepemimpinan di Kabupaten Wonosobo dalam Kebijakan Pembangunan Pertanian Berkelanjutan. Jurnal Sosial Ekonomi dan Kebijakan Pertanian, 6 (2), 231-238.

Badan Pusat Statistik. (2017). Statistik Indonesia Tahun 2017. Jakarta: Badan Pusat Statistik.

Badan Pusat Statistik. (2016). Kabupaten Sukoharjo Dalam Angka Tahun 2016. Sukoharjo: BPS Kabupaten Sukoharjo.

Berutu, N., Lumbantoruan, W., Astuti, A.J.W., dan Rohani. (2015). Analisis Daya Dukung Lingkungan Daerah Aliran Sungai Deli. Jurnal Pengabdian Kepada Masyarakat, 21 (79), 78-84. 


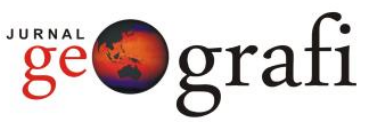

Direktorat Jenderal PSP. (2014). Potensi Alih Fungsi Lahan Akibat Tidak Diterapkannya LP2B dalam RTRW Kab./Kota dan Pencetakan Lahan Baru. Jakarta: Direktorat Jenderal Prasarana dan Sarana Pertanian.

FAO. (1996). World Food Summit, 13-17 November 1996. Rome, Italy: Food and Agriculture Organisation of the United Nations.

Handani, L. N, Wasino, dan Muntholib, A. (2017). Dinamika Produksi Beras dan Pengaruhnya Terhadap Ketahanan Pangan Masyarakat di Kabupaten Grobogan Tahun 1984-1998. Journal of Indonesian History, 6 (1): 46-54.

Kurniawan, A. dan Sadali, M. I. (2015). Keistimewaan Lingkungan Daerah Istimewa Yogyakarta. Yogyakarta: Gadjah Mada University Press.

Kementerian Pertanian. (2014). Strategi Induk Pembangunan Pertanian. Jakarta: Biro Perencanaan, Sekertariat Jenderal Kementerian Pertanian.

McGee, T. G. (1991). The Emergence of Desa-Kota Regions in Asia: Expanding a Hypothesis. McGee, T. G., Gimberg, N., (eds). Hawai: University of Hawaii Press.

Mulyani, A., Nursyamsi, D., dan Syakir, M. (2017). Strategi Pemanfaatan Sumberdaya Lahan untuk Pencapaian Swasembada Beras. Jurnal Sumberdaya Lahan, 11 (1), 11-22.

Mulyani, A., Kuncoro, D., Nursyamsi, D. dan Agus, F. (2016). Analisis Konversi Lahan Sawah: Penggunaan Data Spasial Resolusi Tinggi Memperlihatkan Laju Konversi yang Mengkhawatirkan. Jurnal Tanah dan Iklim, 40 (2), 43-55.

Rusdiana, S. dan Maesya, A. (2017). Pertumbuhan Ekonomi dan Kebutuhan Pangan di Indonesia. Jurnal Sosial Ekonomi dan Kebijakan Pertanian, 6 (1), 12-25.
Sadali, M. I. (2016). Mobilitas Pekerja Pada Kawasan Industri Piyungan di Kabupaten Bantul, Daerah Istimewa Yogyakarta. Jurnal Patrawidya, 17 (3): 83-98. Yogyakarta: Kementerian Pendidikan dan Kebudayaan, Balai Pelestarian Nilai Budaya, DIY

Sadali, M. I. (2014). Trend Perkembangan Penduduk dan Implikasinya Terhadap Kebutuhan RTH (Ruang Terbuka Hijau) di D.I. Yogyakarta. Prosiding Pertemuan Ilmiah Ikatan Geograf Indonesia (IGI). Eds. Hastuti et al. hlm 366-379. Yogyakarta: Jurusan Pendidikan Geografi UNY.

Sintong, M. (2011). Pemanfaatan lahan Bekas Tambang untuk Tempat Rekreasi dengan Reklamasi di Sungai Bingai Kecamatan Banjai Selatan Kodya Binjai. Jurnal Geografi, 3 (2), 1118.

Suhardjo dan Tukiran. (1990). Studi Literatur Konsep yang Sudah ada Mengenai Daya Tampung Wilayah. Jakarta: Kantor Menteri Negara Kependudukan dan Lingkungan Hidup.

Syarief, R., Sumardjo, Kriswantriyono, A., dan Wulandati, Y.P. (2017). Pengembangan Ketahanan Pangan Melalui Pemberdayaan Masyarakat di Kawasan Rawan Konflik Timika Papua. Jurnal Ilmu Pertanian Indonesia, 22 (3), 163-171.

Syahril, A.T. dan Bahari, D. (2015). Preferensi Konsumsi Beras Berlabel. Agriekonomika, 4 (1), 10-21.

Wahyunto dan Widiastuti, F. (2014). Lahan Sawah Sebagai Pendukung Ketahanan Pangan serta Strategi Pencapaian Kemandirian Pangan. Jurnal Sumberdaya Lahan, 17-30.

WFP Indonesia. (2015). Peta Ketahanan Pangan dan Kerentanan Pangan Papua. Jayapura: WFP Papua. 